\title{
Life Style and Risk Behavior of Street Children in Bangladesh: A Health Perspective
}

\author{
Sajeda Chowdhury ${ }^{1}$, Abu Sayeed Chowdhury², KATM Ehsanul Huq², Yasmin Jahan², \\ Rubana Chowdhury33, Toufiq Ahmed ${ }^{4}$, Md Moshiur Rahman ${ }^{*}$ \\ ${ }^{1}$ Institute of Biomedical \& Health Sciences, Hiroshima University, Hiroshima, Japan \\ ${ }^{2}$ Graduate School of Biomedical \& Health Sciences, Hiroshima University, Hiroshima, Japan \\ ${ }^{3}$ Department of Chemistry, National University, Dhaka, Bangladesh \\ ${ }^{4}$ Japan Advanced Institute of Science and Technology, Nomi, Ishikawa, Japan \\ Email: *moshiur670@gmail.com
}

How to cite this paper: Chowdhury, S., Chowdhury, A.S., Huq, K.E., Jahan, Y., Chowdhury, R., Ahmed, T. and Rahman, M.M. (2017) Life Style and Risk Behavior of Street Children in Bangladesh: A Health Perspective. Health, 9, 577-591.

https://doi.org/10.4236/health.2017.94041

Received: March 16, 2017

Accepted: April 4, 2017

Published: April 7, 2017

Copyright $\odot 2017$ by authors and Scientific Research Publishing Inc. This work is licensed under the Creative Commons Attribution International License (CC BY 4.0).

http://creativecommons.org/licenses/by/4.0/

\begin{abstract}
Background: Street children concern to millions of deprived boys and girls who have adopted the street as their residence. They grow up where tranquility and physical and emotional stability are frequently threatened. The purpose is to have an empathetic look into the lives of street children for identifying their health-related needs. Method: A cross sectional descriptive type of study was conducted among 125 street children between the ages 8 to 14 years who were available at different intercept points of Dhaka city, Bangladesh. The information was collected through face-to-face interview using a structured questionnaire. An attempt was made to relate their lifestyle, risk behavior and health impact upon the socio demographic characteristics. Result: According to the statement of street children, poverty (41\%) is the main reason behind enforcing the children to stay and work on the street. They pass their leisure by playing games, roaming around by watching video/cinema but on the other side of the coin, they are frequently abused (80.8\%) either physically or sexually. Regarding health, about $87.2 \%$ of street children were suffering from different type of diseases as accidental injury, skin infection, hepatitis, sexually transmitted diseases and warm infestation. Conclusion: A careful examination of the lives of these children will provide a clearer understanding of their disadvantageous life. A better diagnosis of the contributing factors will help to minimize the extent of the problems and also to develop innovative approaches and ensure a healthy lifestyle, protection and rehabilitation for those children.
\end{abstract}

\section{Keywords}

Street Children, Life Style, Risk Behavior, Bangladesh 


\section{Introduction}

A street child is any child who works and or lives in the street [1]. The term street children refer to millions of destitute boys and girls who have adopted the street as their abode or source of livelihood, or both [2]. Their survival or subsistence depends on their own activities in the street. In low developed and developing countries, street children lie in a special category of children mostly due to difficult circumstances which is basically an urban phenomenon. The definition of this category of children is quite problematic in the process of being clarified. It can be referred initially as all urban children who spent most of their time on the streets, whether working or not. Both the street and working children may often suffer abuse and negligence. Many children in situations of armed conflict or due to from getting affected by natural disasters become street worker children. The main point is, all these children have been abandoned in some ways [3]. There are two groups of street children. The first group is "Children of the street", which refers to children who are homeless, and their source of livelihood is in the streets of urban areas, where they sleep and live. The second group is "Children on the street", who work and live on the streets in the daytime but return back home at night where they sleep, although some of them sleep seldom on the streets (UNCHS, 2000) [4].

Children living on the streets are particularly vulnerable to abuse and exploitation. These children also endure augmented risks to their protection and well-being. Many of them work, often in perilous and low-wage jobs, to sustenance themselves and their families. Street children are often abused or oppressed by policemen who frequently beat them, ask for bribes, take away their plunders and incriminate them in false charges. Common social perspective towards street children is full of negligence which further segregates them from the mass community. Nonetheless, according to the United Nations Convention on the Rights of the Child (UNCRC), it is identified that every child is authorized to a standard of living adequately for the child's physical, mental, spiritual, moral and social development [5]. It is evident from the example of developed welfare societies in the world that to build a prosperous future, the most important thing is to ensure appropriate nurturing of younger generation. The future of every nation depends on how children prepare themselves to enter into the working age period. Children who are well-fed, healthy and educated grow up to be productive, innovative workers and responsible adults [6].

According to United Nation's (UN) estimation, there remain about 150 million street children worldwide [7]. More than half of them are exposed to the worst forms of child labor such as slavery, physical torture, trafficking and prostitution. Extensive criminal networks make substantial profits by engaging children in commercial sex work, smuggling, stealing, and the distribution of drugs and weapons [5] [8]. The existence of street children can be found in almost every part of the world and the majority of them reside in the urban areas of developing countries [9]. In recent years, the problem has been becoming 
much worse due to economic problems, political changes, social unrest and degradation of values, family separations and conflicts, natural disasters and the epidemic spread of diseases [10].

Nearly half of the world child population can be found in the Asia-Pacific region with large numbers of street children. The children on the street, or children who previously lived on the street, are being used in a variety of occupations including sex industry, beggar, shoeshine boy or flower seller, rubbish picker, sweat shop worker, petty criminal, etc. The Asia and Pacific region has diversified economic and political systems that consist of totally different contexts as a result of which children unluckily become dwellers of the streets. The problems they face on the street, their prospects for moving to the street living, and a wide range of government as well as civil society responses and interventions has been considered as a matter of significant research interest. However, the number of street children is still on a rising trend [11].

The People's Republic of Bangladesh is located in South Asia; Dhaka is its capital as well as the largest city. Despite sustained domestic and international efforts to improve economic and demographic prospects, Bangladesh remains a poor, overpopulated and ill-governed nation. In case of Asian Development Bank's developing member countries, children under 14 years old make up 30\% of the population. When this vulnerable group does not get appropriate facilities, they suffer from malnutrition and many other basic life problems which affect their overall growth, community development from the very early life, which ultimately causes rise of a poor developed nation [12]. Children with elementary factual requirements cannot be optioned within the domiciliary move to the street [13]. It is estimated that there is more than 600,000 street children living in Bangladesh, 75\% of them live in the nation's capital, Dhaka [14]. With increasing landlessness in rural areas and consequent large-scale rural-urban migration, the number of 'floating' people in urban areas of Bangladesh is on the increase. In particular, the prevalence of destitute children (Tokai) is increasing rapidly. They are either homeless, having no fixed address, or are residing in streets, slums and squatter settlements. They are not only living in a healthy environment rather they themselves are creating environmental threats to the society as a whole, in various ways [15].

In Dhaka city, about a quarter of the population are slum dwellers. They are in a vicious circle of too little or inadequate food, poor nutrition, polluted water and air, lack of education, poor sanitation and overall levels of living that can be termed as an environment breeding suspicion and violence. In reality, a slum contains swamp of mud, excrement, garbage, mosquitoes and disease; and these have been growing in the big cities during the last two decades. The conditions of slum children are worse [16] [17].

Street children are usually treated with utmost negligence as nobody smiles at them, cuddles them, protect them and give them comfort. They have no helping hand for their existence and survival except their own efforts. There is a need to move beyond a vision of these street children, which encompasses the origins of 
their problems in their family, community, school, work and leisure setting hindering their physical and mental development [18]. This study has been performed in response to the pressing need to assess the personal and social consequences of the urban street children. The purpose of this study is to have a close and empathetic look into the lives of street children and to find out the life style of street children with a special reference to their risk behaviors.

\section{Methodology}

\subsection{Study Design}

It was a descriptive cross-sectional study. The data collection activities for this study were performed from May to June 2007 in Dhaka city, Bangladesh. The selected areas for interview were city intercept points like Kamalapur Station, Sadarghat Launch Terminal, Ramna Park, Shishu Park, Dhaka University campus, Shahbagh, New Market, Chandrima Uddyan, Dhanmondi Lake, National Zoo, Botanical Garden, some road island of Gulistan and Moghbazar, Panthapath, Airport Station, and Saidabad Bus Terminal (Figure 1).

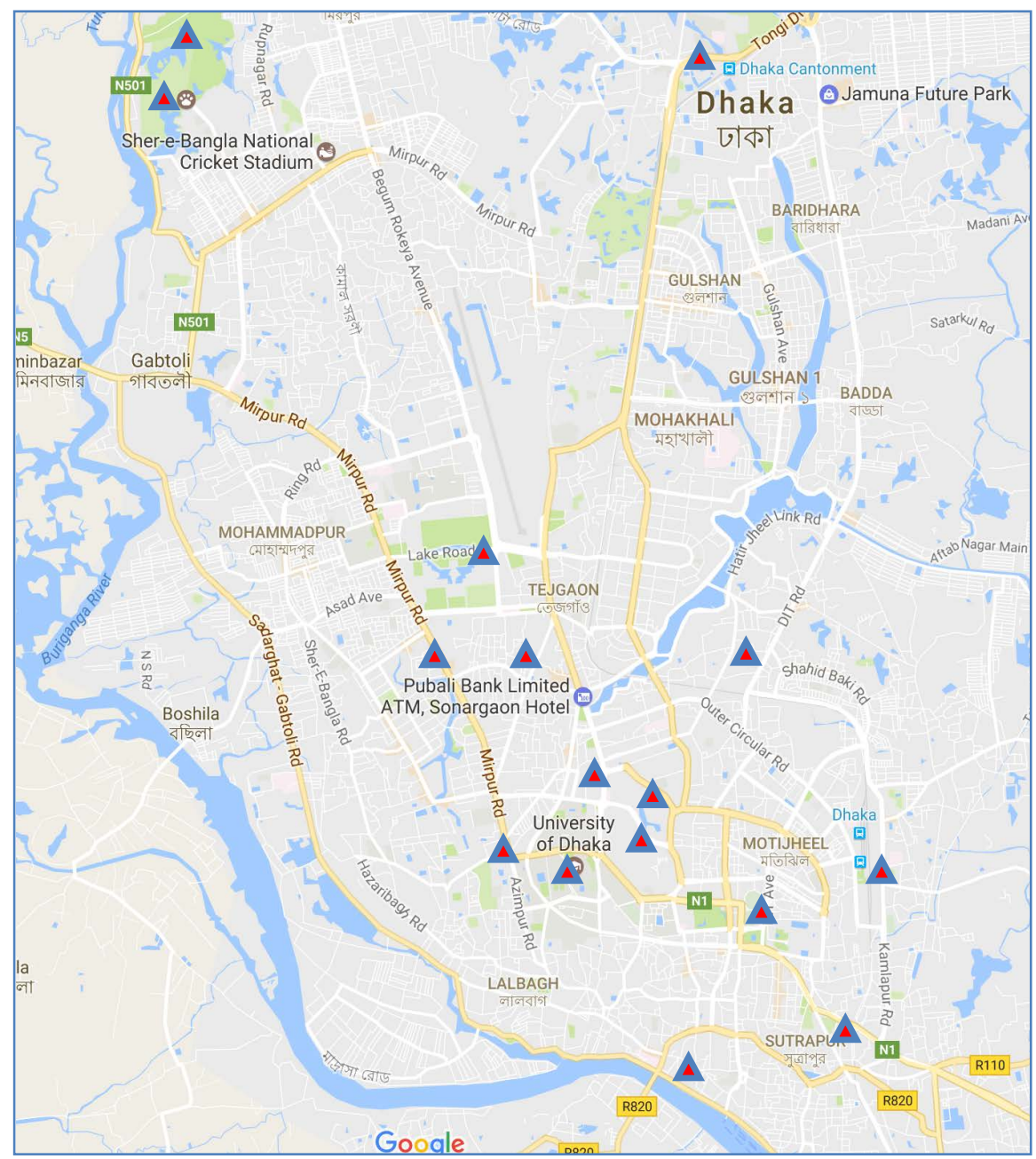

Figure 1. Intercept points in Dhaka city where the survey was conducted among street children. 


\subsection{Inclusion Criteria}

- The target population was street children who spend most of their times on the street or in an open place.

- Age of 8 - 14 years of both sexes.

\subsection{Exclusion Criteria}

The children below 8 and over 14 years are not included in the study.

\subsection{Sample Size and Sampling Technique}

Considering the nature of study and length of time the sample size was limited to 125 . The children were approached and the purpose and type of interview were explained. Whoever participated willingly was included as a respondent. Sampling technique was non-probable purposive type.

\subsection{Data Collection and Analysis}

An interview schedule was prepared to guide the researcher during interview. It was pre-tested among some street children. Almost all questions were structured in nature except a few open-ended questions. An attempt was also made to relate their lifestyles, risk behavior and health impact regarding the socio demographic characteristics. The questionnaire included source of income, occupation, stay and working place, source of drinking water, sanitation, types of illness, abuse and harassment. The information was collected through face-to-face interview. The interview not only consisted calling the children and asking them questions, the researcher also attempted to know the children in different territory and passed a considerable amount of time to establish enough rapport to make them comfortable so that they can openly express their condition. The researcher also repeatedly visited around the same area and sometimes passed time gossiping with the children to develop trust between the researcher and the respondents. After that, the respondents were requested to tell about their own life through asking one or two questions or by explaining what type of answer is expected from them. The respondent was allowed to continue freely and the researcher only asked some probing questions whenever necessary. Each interview required approximately 45 minutes on an average. In most of the cases the interviews were recorded with a tape recorder except when it was not allowed or when the respondent felt uneasy to talk in front of a tape recorder. After finishing an interview, the researcher finally filled up the data sheets with complete information. Additional information was written in an extra sheet and tagged with the questionnaire. The collected information was compiled, tabulated and analyzed by the researcher.

\subsection{Ethical Considerations}

The study was approved by the ethics committee of National Institute of Preventive \& Social Medicine, Dhaka, Bangladesh. The survey was conducted anonymously, and data were collected from the street children who agreed to partici- 
pate. The data were kept strictly confidential and promised not to use outside of this study. The participants were informed that their involvement in the study was entirely voluntary, and they may choose to withdraw at any time without hesitation or fear.

\section{Results}

In this study, a total of 125 participants were enrolled and analyzed. The majority of the children aged between 8 to 10 years (45.6\%) and mostly consisted of boys $(87.2 \%)$. Mean age was 11.22 (Table 1 ). Almost half of the children were

Table 1. Socio-demographic profile of the study population.

\begin{tabular}{|c|c|c|}
\hline Parameter & Frequency & Percent \\
\hline \multicolumn{3}{|c|}{ Age-group } \\
\hline $8-10$ years & 57 & $45.6 \%$ \\
\hline $11-12$ years & 24 & $19.2 \%$ \\
\hline $13-14$ years & 44 & $35.2 \%$ \\
\hline \multicolumn{3}{|c|}{ Gender } \\
\hline Boy & 109 & $87.2 \%$ \\
\hline Girl & 16 & $12.8 \%$ \\
\hline \multicolumn{3}{|c|}{ Parents living place } \\
\hline Urban & 47 & $37.6 \%$ \\
\hline Rural & 52 & $41.6 \%$ \\
\hline Dead & 24 & $19.2 \%$ \\
\hline Others & 2 & $1.6 \%$ \\
\hline \multicolumn{3}{|c|}{ Level of education } \\
\hline Illiterate & 62 & $49.6 \%$ \\
\hline Primary & 38 & $30.4 \%$ \\
\hline Secondary & 3 & $2.4 \%$ \\
\hline Only can sign & 7 & $5.6 \%$ \\
\hline Only can read Arabic & 4 & $3.2 \%$ \\
\hline Only can read & 11 & $8.8 \%$ \\
\hline \multicolumn{3}{|c|}{ Use of latrines } \\
\hline Public latrine & 58 & $46.4 \%$ \\
\hline Open space & 37 & $29.6 \%$ \\
\hline Kacha latrine (Unhygienic) & 30 & $24.0 \%$ \\
\hline \multicolumn{3}{|c|}{ Amount of earned money (in Bangladeshi Taka) } \\
\hline$<50$ & 52 & $41.6 \%$ \\
\hline $51-100$ & 30 & $24.0 \%$ \\
\hline $101-150$ & 19 & $15.2 \%$ \\
\hline $151-200$ & 12 & $9.6 \%$ \\
\hline$>200$ & 9 & $7.2 \%$ \\
\hline
\end{tabular}


found illiterate $(49.6 \%)$ and a few of them previously entered in secondary school (2.4\%). Table 1 shows $49.6 \%$ of respondents had never attended any school, where as $50.4 \%$ had exposure to formal or irregularly attending non-formal school. Analysis of collected data found that $30.4 \%$ of respondents had exposure up to primary level, $2.4 \%$ had exposure up to secondary level, $5.6 \%$ of respondents could only write their name as signature, $3.2 \%$ received education from religion oriented institutions, therefore, only had Arabic language reading ability and $8.8 \%$ could only read. Their daily earning was extremely low in local currency Bangladeshi taka (BDT) and most of them (65.6\%) have the regular income less than $100 \mathrm{BDT}$ in a day (Table 1). The mean income was 94.26.

Figure 2 shows that about $41 \%$ of respondents stated poverty as the prime factor for them to get out of their family and take place in the street. $13.1 \%$ had come due to being victim of physical abuse by family members and $11.5 \%$ due to unaccepted insistence of step mother/father in their personal life. Another 11.5\% were brought by unknown person, $9.8 \%$ came with relative, $8.2 \%$ to earn money, $3.3 \%$ ran away with friends and in $1.6 \%$ cases there was no one to look after (Figure 2).

The study shows that, $21.3 \%$ of respondents did not stay with their parents though their parents lived in this city, and rest of the $78.7 \%$ lived with their parents. The reasons behind this were: parents wanted them to live their own by themselves, unbearable influence of stepmother, abuse by family members, and due to presence of stepfather. Regarding parent's profession, about fathers' occupation, $21.5 \%$ were involved in micro business, $20.4 \%$ were daily laborer, $17.2 \%$ were rickshaw puller, $8 \%$ were farmer, $4.3 \%$ doing private job, $2.2 \%$ in Government job, 3.2\% unemployed, and $22.6 \%$ were in other different jobs. In case of mothers, $40.4 \%$ were house wives, $32.1 \%$ were part time housemaids, $19.3 \%$ were daily laborers, $4.6 \%$ were involved in private job and 3.7\% did micro business.

Table 2 reveals that $22.4 \%$ of respondents stayed at different streets at day time, $23.2 \%$ at railway station, $9.6 \%$ at park, $7.2 \%$ in University area, another $7.2 \%$ in bus station, $6.4 \%$ at launch terminal, $4.8 \%$ in market places, $4.8 \%$ in footpath and some multiple responses were also seen because the same child passed the day both in the park and adjacent footpath.

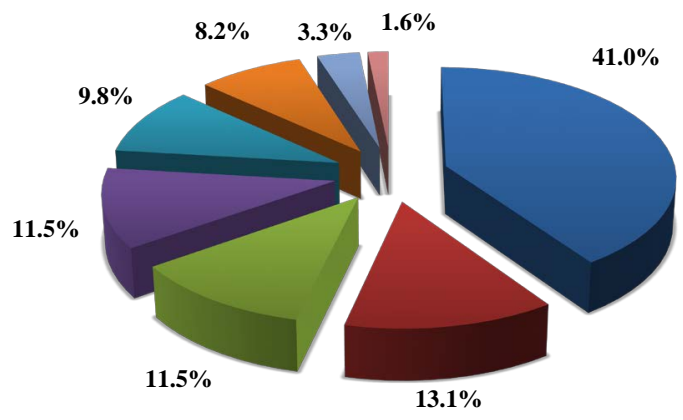

Figure 2. The factors for becoming street children.

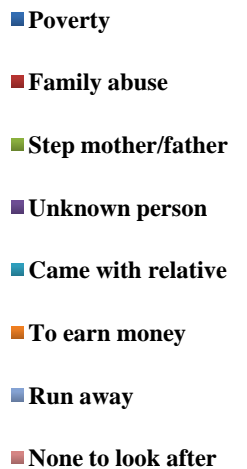

None to look after 
The street children were involved in various types of jobs. According to the data analysis, $32.8 \%$ of respondents worked as cooli/minti (labor), 9.6\% were beggars, $8.8 \%$ sold flower, $8 \%$ sold chocolate/cigarette, $3.2 \%$ were news paper sellers, $10.4 \%$ of respondents had multiple job and $19.2 \%$ of respondents used to collect discarded plastic bottle (Table 3 ).

In this study, $53.6 \%$ of respondents performed daily morning wash with supply water, $22.4 \%$ with tube well water, $1.6 \%$ with open lake water, $8 \%$ with water from hotel/shop, $8.8 \%$ did not take wash. Among the children, $31.2 \%$ took breakfast on the street, $28 \%$ in hotel, $17.6 \%$ in shop or terminal, $12 \%$ in home, $5.6 \%$ at NGO school and another $5.6 \%$ at launch terminal. Regarding water usage, in $53.6 \%$ cases source of drinking water was supply water, hotel/shop in $26.4 \%$ cases, from tube well in $8 \%$ cases, and from both supply water \& shop in $12 \%$ cases. Regarding sanitation issue, used toilet was public toilet in $46.4 \%$ cases

Table 2. The place where the street children stay through out the day.

\begin{tabular}{ccc}
\hline Place of stay & Frequency & Percentage \\
\hline Different street & 28 & $22.4 \%$ \\
Launch terminal & 8 & $6.4 \%$ \\
Bus station & 9 & $7.2 \%$ \\
Railway station & 29 & $23.2 \%$ \\
Market & 6 & $4.8 \%$ \\
Foot path & 6 & $4.8 \%$ \\
Park & 12 & $9.6 \%$ \\
University area & 9 & $7.2 \%$ \\
Different street and market & 5 & $4.0 \%$ \\
Different street and footpath & 4 & $3.2 \%$ \\
Different street and park & 9 & $7.2 \%$ \\
\hline
\end{tabular}

Table 3. The job pattern performed by the street children.

\begin{tabular}{ccc}
\hline Nature of work & Frequency & Percentage \\
\hline Rag picking & 10 & $8.0 \%$ \\
Flower selling & 11 & $8.8 \%$ \\
News paper selling & 4 & $3.2 \%$ \\
Chocolate/cigarette selling & 10 & $8.0 \%$ \\
Beggar & 12 & $9.6 \%$ \\
Cooli/minti & 41 & $32.8 \%$ \\
Rag picking and flower selling & 4 & $3.2 \%$ \\
Rag picking and collect things from dustbin & 3 & $2.4 \%$ \\
Cooli/minti and pick pocketing & 6 & $4.8 \%$ \\
Others & 24 & $19.2 \%$
\end{tabular}


in different places, open places in $29.6 \%$ of cases and in $24 \%$ of cases open pit latrine. Regarding the way of passing leisure period, $31.2 \%$ respondents mentioned about playing, $27.2 \%$ roamed around, $13.6 \%$ by watching movie in Cineplex, $8.8 \%$ by taking care of younger brother \& sister, $7.2 \%$ by watching TV, $5.6 \%$ by both roaming around \& taking care of younger brother \& sister, and $3.2 \%$ by both watching movie and roaming around (Table 4).

During the study time, $87.2 \%$ were suffering from different diseases while $12.85 \%$ did not mention about existence of any disease. As per the respondents, $44.0 \%$ were suffering from accidental injury, $17.4 \%$ from skin disease, $13.8 \%$ from gastrointestinal (GIT) problem, 10.1\% from fever, 5.5\% from hearing problem, $5.5 \%$ from respiratory tract infection and $21.1 \%$ from fever with respiratory tract infection (Figure 3 ).

In case of the treatment seeking pattern, $47.7 \%$ of respondents depended on salesman of the pharmacy, $12.8 \%$ on NGO workers, $4.6 \%$ on traditional healer, $2.8 \%$ on Kabiraj (herbal medicine), $1.8 \%$ on homeopath and $28.4 \%$ did not take any type of treatment (Figure 4).

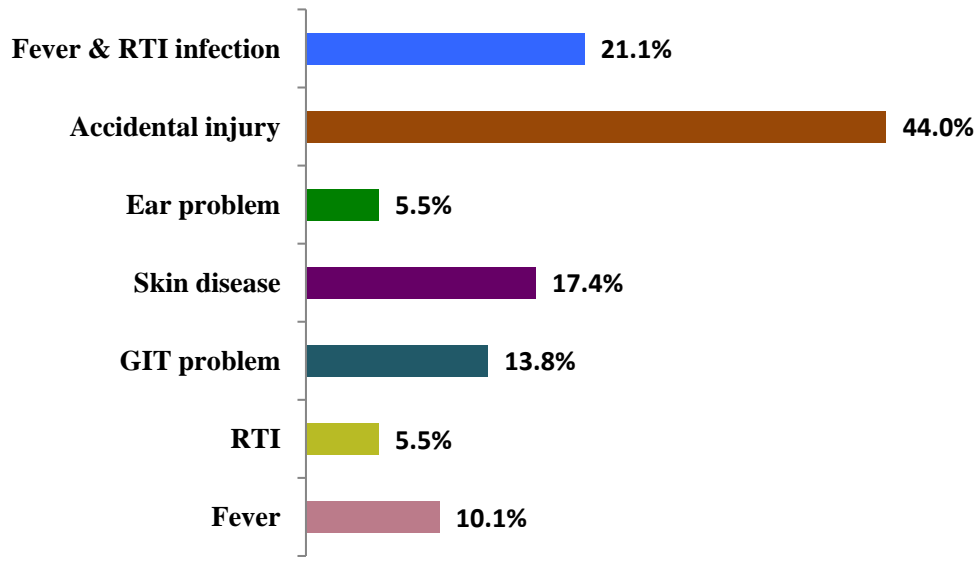

Figure 3. The diseases reported by the street children in this study. RTI: Respiratory tract infection, GIT: Gastrointestinal tract.

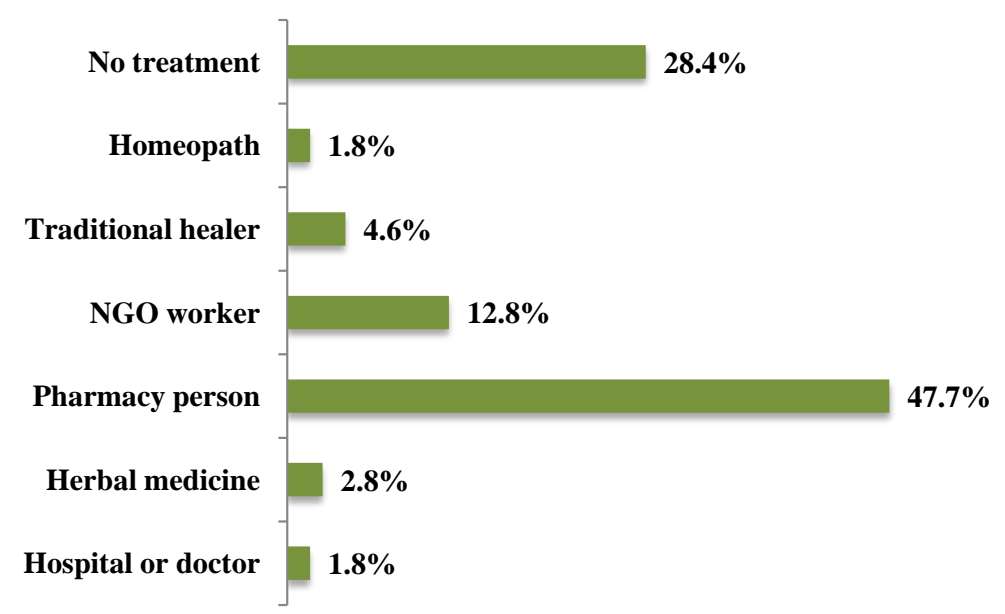

Figure 4. The treatment seeking pattern in this study. NGO: Non governmental organization. 
Table 4. The way of passing leisure time by the street children.

\begin{tabular}{ccc}
\hline Way of passing leisure period & Frequency & Percentage \\
\hline Play & 39 & $31.2 \%$ \\
Cinema or video & 17 & $13.6 \%$ \\
Roaming around & 34 & $27.2 \%$ \\
Watching television & 9 & $7.2 \%$ \\
Take care of younger brother \& sister & 11 & $8.8 \%$ \\
Cinema and roaming around & 4 & $3.2 \%$ \\
Roaming around, take care of brother \& sister & 7 & $5.6 \%$ \\
Others & 4 & $3.2 \%$ \\
\hline
\end{tabular}

As regards of the skin condition, $59.25 \%$ of respondents had skin disease/injury marks and $36 \%$ had normal skin condition. The scenario of abuse highlighted that $80.8 \%$ of respondents were abused by any means, whereas $19.2 \%$ had no such experience. Among the abused, $44 \%$ were abused physically, $9.6 \%$ of respondents were abused physically, mentally \& sexually whereas $27.2 \%$ were abused both physically and mentally.

About their night shelter, $37.6 \%$ of respondents mentioned about slums, $14.4 \%$ mentioned footpath, $11.2 \%$ of respondents' night shelter was railway station, for $7.2 \%$ of respondents night shelter was bus station, for $5.6 \%$ market, for $4.8 \%$ lunch terminal, for $4.8 \%$ NGO club, and for $12 \%$ night shelter were other different places. This study reveals that, street children usually prefer to sleep with other street children in different night shelters. In slum area, $30.4 \%$ respondents used to sleep with family members, $12.0 \%$ slept alone in different night shelters where $9.6 \%$ used to sleep with friends and $4.0 \%$ slept with other adults in different night shelters.

\section{Discussion}

In this study, the ratio of the sex interrelates the findings of other national and international studies. Commonly, the boys are greater and the girls are less in number in the street all over the world. A study in Brazil [18] suggests that families try to keep girls at home either to help the housework or to avoid their falling into prostitution.

Most of the young girls feel insecure in the street. A study on Calcutta's street children [19] stated that street girls without exception were disgusted with the life they lead and each one of them was keen to come out of her present life. Furthermore, another study in Bangladesh [20] identified the familial psychological reason behind this phenomenon; that is those are parents with same psychological perception who send their son to earn money on the street of a big city or find a job for their daughter as a maid.

In case of this study, about two third of the respondents came from the villages either with the objective of earning their livelihood or because of being victims of child abuse. Poverty seems to be the main cause of this migration to ur- 
ban areas. The claim is very well evidenced by the distributions of parents' occupation, which invariably shows that the parents of these children were holding low earning jobs. The ongoing economic hardship in the family, in the first place, along with the opportunities of earning attracted the children to come out of their family to the street. It is seen that most of the respondents' mothers were housewives that appeared to be non-income generating role. As a result, the mothers had to be dependent on others (husband/relatives) and were unable to support their children. Consequently, the mothers encouraged their children to go out of the family and look for earning opportunities in the city streets [21]. In some instances, the respondents were forced by their parents to leave the family to seek out the opportunities of earning. The previous studies in Bangladesh [22] identified the attributes for being on the street as poverty, abandoned child, step mother/father and victims of abuse or neglect or migration from village to city.

The researcher found that children do not like to change their dwelling places frequently. All the interviews had been made at daytime, which was mainly the working time for all these children. However, all of them were found very near to their dwelling places. It was found from the interviews that there were some factors, which dictated this distinguished behavior of the children. After being settled in one place with accommodation, they felt insecure to change the place and to be unsettled again. Their interaction with other children of the same area was very friendly and sympathetic. They protected one another from unnecessary troubles during work time and also at night. So, this peer group feeling and protection restricts them from changing the shelter frequently, unless it is absolutely necessary. Consequently, sometimes it was not easily possible for them to change their dwelling places.

This behavior of the children is probably true for all the Mega cities of the world. A study on Mexico City said that street children did not wander erratically throughout the city [18]. Their place of work was determined by a variety of conditions, such as the wishes of some unseen employer, or by the extent of the area where friends carried out commercial or begging activities. All these factors concerning the lives of street children indicated normal human needs for friends and association, sense for safety and security, needs for job expertise and earning. Although they were rootless in terms of family and home, still, they were not baseless in terms of association they grew with and the peer feeling they possessed.

At night more than half of the children lived without any of their family members; out of whom, few of them slept completely alone. All the shelters like, park, station, slum, market, verandas, terminals, were almost open spaces and not protective from weather in any circumstances. Life in the street obviously forces these children to be exposed to various unhealthy and injurious elements like smoke, dust, sun, rain, etc. While asked about the problems of street life that they encountered, a boy innocently uttered, "It is too cold during winter."

All the children needed to work to meet their daily expenditure, mainly low-income jobs. The most popular works for these street children of both sexes were begging. More than half of the responses had come for the above works. 
Other occupations like newspaper or chocolate hawkers, shoeshine boys, popcorn seller were also common. For example, male children were more involved with the works like porter of the stations, terminals and markets, some anti-social earning like muscleman ship, smuggling, pick pocketing, stealing. On the other hand for the girl it is easy to become commercial sex worker. These diversified nature of jobs had a direct influence on the daily routine of these children. Consequently, their distribution of working hours and total sleeping hours varied widely depending on the nature of the work they do.

Most of the respondent reported that they were suffering from some diseases. These diseases were mainly skin disease, respiratory problems, abdominal disorder, eye and ear problem (Figure 3). Most of the children had visible skin disease. There were some factors involving the lives of these street children to become infected with these skin diseases commonly. They are overcrowded living condition, unhealthy sleeping area, irregular bath, and less changing of cloths. It is evident that these children were living in an overall poor condition and the skin problem that they had was "scabies" which was very infectious and contagious. So, the spreading of this disease was easily possible. Also, the children commonly had infected cuts and bruises that were considered as a skin problem in this study. On the contrary, a Mexico City study reported that respiratory and gastro-intestinal problem were the main health problems, which arose from this environment (pollution and contaminated food and water) [18].

The common abdominal diseases that had come out through interviewing the children are abdominal pains, chronic diarrhea, worms, and acidity. The primary reasons for having these abdominal disorders were eating in the hotel, eating of thrown away foods and rotten foods. Furthermore, the main respiratory problems were common cold, cough, fever \& asthma. Also, some isolated health problems like night blindness, impaired vision, earache and deafness were present among few of the children. A study in Kenya determined almost the same health problems of street children as respiratory and skin disease were the leading causes of morbidity [23]. Another study in Bangladesh reported that the street children not only had different types of skin diseases but also some sexually transmitted disease (STD) like hepatitis and syphilis [24].

As a result of these diseases, the children had to use some sort of treatment facilities. Most of them were dependent on salesman of pharmacy. Some of them used to avail traditional treatments like "Kabirazi" or "homeopathy". Now a day they also prefer hospital and NGO worker.

The children frequently experienced verbal or physical abuse from adults whenever they used to take a seat in front of a shop, lean on the cars, enter a public building, etc. The children felt that they were constantly misbehaved by the adults [25]. They have faced a daily routine of exploitation and violence and like other street children in the world often ended up in a life of crime. The report says it is impossible to calculate exactly how many street children there are in total, but it is generally thought to be approaching two million [26].

The street children were in a favorable condition for experiencing sex. The 
study identified several ways of having these experiences. For male, the main reason was relation with commercial sex worker and for females; the main reason was currently working or previously working as commercial sex worker. The free access of sex in the street actually threatened the lives of these children as well as the society. Relating with the other city studies of the world, this group of children of Dhaka can be considered as one of the specific social group who are most susceptible to sexually transmitted diseases (STDs) and AIDS. A global statistics specified these social groups and reported teenagers especially urban street children are at particular risk for STDs [27].

Usually, street children preferred independent living. So, when their income rose, in search for enjoyment, they usually felt attracted to different types of addiction. Mainly they were smokers but there were evidence of taking drugs among the children. Interestingly, the children reported that these drugs were readily available for them in the pharmacies.

\section{Study Limitation}

In this research the study areas do not represent the whole Dhaka city and the sample size was too small which was the main limitation. Again, no nutritional data has been measured and the study questionnaires were not in-depth probing pattern due to time limitation.

\section{Conclusion}

The study findings advocate that poverty is the foremost reason behind imposing the children to stay and work on street. Regarding health, most of the street children were suffering from different type of diseases while accidental injuries and skin infection are topping the list. In consideration to the country context, it can be alleged that government should take some obligatory steps to secure their life and as well as social leaders can be involved to advance their lifestyle.

\section{Recommendation}

The physiognomies and necessities of street children are very diverse. They need different types of retorts. They strive to attain education, look after their health, enjoy frivolous occasions, swap their jobs. On the other hand, street children entail distinct devotion for vocation instruction, masculinity edification, and knowledge about how to pact with family skirmishes. In a study, it was suggested that welfare department of government bodies (GO), non-government organization (NGOs) and respective families can take the initiatives for resolving and prevent the increase of street children. GO, NGOs and international human activist bodies can evaluate the existing burden and plan for appropriate solutions. Government Welfare department can organize committees, hold conference and plan common program. Government should develop some strategies about educational accessibility, nutritional education, behavioral edification, and living amenities for street children. Moreover, safeguards should be needed during 
working or living on the street to prevent risks like physical, moral, social and develop themselves as a self-protector. NGOs can establish education centers and awareness program. International bodies can hold workshop, provide financial and technical support to government. To get better solutions macro, medium and micro level planning for long-term, mid-term and short-term projects need to be implemented. Education for the parents on attitude with children, social and cultural problems and reinforcement of the child protection law can resolve the problems.

\section{Conflict of Interest}

The authors declare that they have no conflicts of interest.

\section{References}

[1] Humanium-Together for Children's Rights (2011) Street Children. http://www.humanium.org/en/street-children/

[2] UNICEF A Study on Street Children in Zimbabwe. https://www.unicef.org/evaldatabase/files/ZIM_01-805.pdf

[3] UNICEF (2005) Though Physically Visible, Street Children Are Often Ignored, Shunned and Excluded. https://www.unicef.org/sowc06/profiles/street.php

[4] UN-Habitat (2000) Strategies to Combat Homelessness. https://unhabitat.org/books/strategies-to-combat-homelessness/

[5] United Nations (2016) World Day against Child Labour. http://www.un.org/en/events/childlabourday/background.shtml

[6] UNICEF (2010) Child Labour in Bangladesh. https://www.unicef.org/bangladesh/Child_labour.pdf

[7] UNESCO (2017). http://www.unesco.org/new/en/social-and-human-sciences/themes/fight-against-di scrimination/education-of-children-in-need/street-children/

[8] The Independent (2016) Street Children in Bangladesh: A Life of Uncertainty. http://www.theindependentbd.com/printversion/details/32932

[9] WHO (2000). http://apps.who.int/iris/bitstream/10665/66756/1/WHO_MSD_MDP_00.14.pdf

[10] Situmorang, A. (2005) Sex and Sexually Transmitted Infections Including HIV/ AIDS among Street Youth in Indonesia WHO. https://www.gfmer.ch/Medical_education_En/PGC_RH_2005/pdf/Street_youth_In donesia_R.pdf

[11] West, A. (2003) At the Margins: Street Children in Asia and the Pacific; Asian Development Bank; Regional and Sustainable Development; Department Poverty and Social Development Papers. https://www.adb.org/sites/default/files/publication/29163/margins.pdf

[12] Asian Development Bank (2003) Working with Street Children, Exploring Ways for ADB Assistance.

https://www.adb.org/publications/margins-street-children-asia-and-pacific

[13] Conticini, A. and Hulme, D. (2007) Escaping Violence, Seeking Freedom: Why Children in Bangladesh Migrate to the Street. Development and Change, 38, 201227. http://www.gprg.org/pubs/workingpapers/pdfs/gprg-wps-047.pdf https://doi.org/10.1111/j.1467-7660.2007.00409.x 
[14] Wikipedia (2017) Street Children. https://en.wikipedia.org/wiki/Street_children_in_Bangladesh

[15] UNICEF (2009) Protection of Children Living on the Streets. https://www.unicef.org/bangladesh/Protection_of_Children_Living_on_the_Streets. pdf

[16] Urbanization in Bangladesh (2003). https://sites.google.com/site/bdguiber/home/6-english/bangladesh/emerging-bangla desh/-urbanization-in-bangladesh

[17] Hossain, S. (2013) Migration, Urbanization and Poverty in Dhaka, Bangladesh. Journal of the Asiatic Society of Bangladesh, 58, 369-382. https://www.asiaticsociety.org.bd/journal/10ShahadatHossain.pdf

[18] UNICEF (1994) Urban Children in Distress: Global Predicaments and Innovative Strategies. https://books.google.co.jp/books?isbn=2881246230

[19] Gosh, A. (1992) Street Children of Calcutta-A Situational Analysis. National Labor Institute, New Delhi.

[20] The UK Department for International Development (DFID) The Nature and Extent of Homelessness in Developing Countries. https://assets.publishing.service.gov.uk/media/57a08d04e5274a27b2001595/R7905.p df

[21] Islam, F. (1995) Street and Working Children in Bangladesh. Child Workers in Asia Foundation, 11, 2-3.

http://web.archive.org/web/20080220120721/http:/www.cwa.tnet.co.th/Publications /Newsletters/vol11_2-3/v11_2-3_street-children.html

[22] Rahman, H. (1989) A Study on the Street Children of Bangladesh. Terre des Hommes, Dhaka.

[23] Ayaya, S.O. and Esamai, F.O. (2001) Health Problem of Street Children in Eldoret, Kenya. East African Medical Journal, 78, 624-629.

https://www.ncbi.nlm.nih.gov/pubmed/12199442 https://doi.org/10.4314/eamj.v78i12.8930

[24] United Nations Population Fund (UNFPA) (2004) Sexually Transmitted Infections Breaking the Cycle of Transmission. https://www.unfpa.org/sites/default/files/pub-pdf/sti_breaking.pdf

[25] Khan, S.A. (1997) Street Children's Research. The Save the Children Fund (UK), Dhaka.

[26] Street Children: The Prevalence, Abuse \& Exploitation of Street Children. http://gvnet.com/streetchildren/00-StreetChildren.htm

[27] Boyden, J. and Holden, P. (1991) Children of the Cities. Zed Books Ltd., London. 
Submit or recommend next manuscript to SCIRP and we will provide best service for you:

Accepting pre-submission inquiries through Email, Facebook, LinkedIn, Twitter, etc. A wide selection of journals (inclusive of 9 subjects, more than 200 journals)

Providing 24-hour high-quality service

User-friendly online submission system

Fair and swift peer-review system

Efficient typesetting and proofreading procedure

Display of the result of downloads and visits, as well as the number of cited articles Maximum dissemination of your research work

Submit your manuscript at: http://papersubmission.scirp.org/

Or contact health@scirp.org 